\title{
Identifikasi Potensi Desa Tawaang Timur Sebagai Salah Satu Daya Tarik Wisata Di Minahasa Selatan
}

\author{
Pearl L. Wenas ${ }^{1}$, Vesty L. Sambeka ${ }^{2)}$, Dimas Ero Permana ${ }^{3)}$ \\ D-IV Hospitality Management \\ Politeknik Negeri Manado, Indonesia \\ Email : lusyepear174@gmail.com, Like_sambeka@yahoo.com, Dimasero01@gmail.com
}

\begin{abstract}
The development of North Sulawesi, specifically South Minahasa, especially East Tawaang Village, has an exciting potential to be developed into a rural tourist destination. First, however, it is necessary to identify what potentials can become the area's backbone to develop these destinations. Therefore, determining the potentials in the area will facilitate the initial steps for strategy preparation and initial mapping as one of the leading destinations in South Minahasa. A qualitative descriptive research method is used to determine the potentials in the village of East Tawaang and is supported by interviews of related people to get valid results. This research shows that the village of East Tawaang has various potentials that can be developed. By formulating a SWOT analysis, it can be found that the Strengths of East Tawaang Village include the potential for nature tourism, culture, and local arts. Natural tourism such as Moinit beach, Songkur beach, mangrove forest, and BTO dam have natural tourist attractions. On the other hand, art tourism which is the basis of the Minahasa art, such as the Kebesaran dance, Lenso dance, and the culture of making traditional cap tikus, needs to be a concern. Weakness of East Tawaang includes many people who have secondary education, infrastructure to get to tourist attractions is still lacking, roads that are still damaged or not even paved, public toilets are not available, restaurants or eating places that have not been formed and adequately organized, service and cleanliness which is very minimal, lodging, souvenir shops that are not yet available must be a priority that needs fixing. The involvement of the local government and local communities is very lacking in understanding the tourism potential in the village of East Tawaang. There are many Opportunities for East Tawaang Village. The potential for nature, arts, and culture should be explored deeper and prepared more thoroughly to become a tourist village. Traditional arts need to be formed and traditionalized to children, adolescents, and young people. Dance studios are made to shape the character of the citizens' arts and culture. They can be displayed in front of tourists visiting potential places, training on handicrafts to make souvenir objects that can be used to drive the tourism economy. The village of Tawaang Timur has threats from other villages if they are late or do not think that the tourism sector is a mainstay of the village. In addition to the threat of competition, the local culture can be lost due to technological developments replacing traditions.
\end{abstract}

Keywords: Identification, Potential, Tourist Attraction

https://doi.org/10.35729/jhp.v4i2.69 
Berkembangnya wilayah provinsi Sulawesi Utara tepatnya Minahasa Selatan khususnya Desa Tawaang Timur mempunyai potensi yang sangat menarik untuk dikembangkan menjadi suatu destinasi wisata pedesaan. Tetapi untuk mengembangkan destinasi tersebut diperlukannya identifikasi potensi - potensi apa yang mampu menjadi tulang punggung kawasan tersebut. Dengan ditentukannya identifikasi potensi di daerah tersebut akan memudahkan langkah awal untuk persiapan strategi dan pemetaan awal sebagai salah satu destinasi unggulan di Minahasa Selatan.Metode penelitian deskriptif kualitatif digunakan untuk mengetahui potensi yang ada di desa Tawaang Timur serta di dukung dengan wawancara orang terkait untuk mendapatkan hasil yang valid. Hasil penelitian dapat diketahui bahwa desa Tawaang Timur mempunyai berbagai macam potensi - potensi yang bisa dikembangkan. Dengan menformulasikan analisis SWOT dapat ditemukan bahwa Strenght atau kekuatan Desa Tawaang Timur antara lain potensi wisata alam, budaya dan seni setempat. Wisata alam seperti pantai moinit, pantai songkur, hutan mangrove,bendungan BTO mempunyai daya tarik wisata alam. Wisata kesenian yang merupakan landasan seni masyarakat Minahasa seperti tari Kebesaran, tari Lenso, Tari Maengket dan budaya pembuatan cap tikus perlu menjadi perhatian. Weakness atau kelemahan Desa tawaang Timur dari segi infrastrutur dan Sumber daya manusia. dari profil desa masih banyaknya masyarakat yang mempunyai pendidikan sangat rendah, infrastruktur menuju ke tempat wisata masih kurang, jalan yang masih rusak atau bahkan belum teraspal, toilet umum yang tidak tersedia, restoran atau tempat makan yang belum terbentuk dan tertata dengan layak, pelayanan serta kebersihan yang sangat minim, penginapan, toko cindera mata yang belum tersedia harus menjadi prioritas yang perlu perbaiki. Keterlibatan pemerintah daerah dan masyarakat setempat sangat kurang dalam memahami potensi wisata di desa tawaang timur. Peluang Desa Tawaang Timur sangat banyak, potensi alam, seni dan budaya seharusnya mampu di ekplor lebih dalam dan dipersiapkan lebih matang untuk menjadi desa wisata karena desa ini mempunyai potensi-potensi yang sangat jarang terdapat di desa lain, seni tradisional perlu dibentuk dan ditradisikan ke anak - anak remaja dan muda, dibuatkan sanggar - sanggar tari untuk membentuk karakter seni budaya warga, dan bisa ditampilkan di depan wisatawan yang mengunjungi tempat - tempat yang berpotensi, pelatihan kerajinan tangan untuk membuat benda - benda cendera mata yang bisa dijadikan penggerak ekonomi wisata. Threat Desa Tawaang Timur memiliki memiliki ancaman dari desa lain apabila mereka terlambat atau tidak memikirkan sektor pariwisata menjadi andalan desa tersebut, Selain ancaman persaingan ancaman budaya setempat yang terdegradasi karena perkembangan teknologi bisa hilang

Kata Kunci : Identifikasi, Potensi, Daya Tarik Wisata 


\section{PENDAHULUAN}

Provinsi Sulawesi Utara mempunyai berbagai macam potensi dan daya tarik yang masih alami dan sebenarnya bisa dikembangkan sebagai daya tarik wisata potensial, tetapi pemerintah daerah selaku stake holder utama kurang memperhatikan pengembangan dan infrastrukturnya, seperti museum Negeri Sulawesi Utara, Vulcano Area Tomohon, Desa Agriwisata Rurukan - Tomohon, Danau Tondano, Bukit Kasih, Cagar Alam Tangkoko Bukit Putih, Batu Pinabentengan, dan Waruga Sawangan. Daya tarik ini sebenarnya mempunyai potensi yang beraneka ragam dan sayang sekali tidak dikelola dengan baik karena sumber daya manusia untuk mengelola masih terbatas dan kurangnya partisipasi masyarakat lokal dalam tugas pengembangan daerah wisata tersebut. Tetapi sedikit demi sedikit destinasi ini mulai mendapat perhatian dari pemerintah daerah dengan adanya promosi melalui media cetak dan elektronik untuk menarik minat wisatawan lokal maupun mancanegara.Pariwisata menjadi salah satu sektor dalam pembangunan di indonesia mengalami pergeseran dikarenakan terjadinya perkembangan industri global yang membuat banyak dari wisatawan mulai mencari alternatif dari wisata berskala mass tourism ke arah suatu kunjungan individu kelompok kecil yang berminat pada aktivitas keseharian kehidupan penduduk di desa atau suatu kawasan tertentu. Oleh karena itu munculah suatu alternatif wisata dimana para wisatawan mampu berinteraksi dengan lebih terbuka terhadap masyarakat dikawasan desa tersebut dan munculah desa wisata menjadi salah satu jawaban dari perkembangan pasar dimana orientasi wisatawan yang dari tipe skala besar menjadi skala kecil yang unik dan menarik.Perubahan trend kecenderungan dalam beberapa dekade memunculkan segmen wisata khusus yang mampu memberikan pengaruh yang sangat signifikan terhadap desa yang mempunyai potensi atau daya tarik wisata. Mereka menyediakan suatu perjalanan ke desa wiata untuk menikmati kehidupan masyarakat serta berinteraksi baik secara langsung dengan masyarakat setempat serta mengenal kebudayaan masyarakat setempat. Berbagai macam atraksi serta potensi wisata di desa dapat mempengaruhi pola kunjungan wisatawan di desa tersebut. Menurut Daldjoeni (1998), setiap desa akan memiliki geographical setting dan human effort yang berbeda - beda satu dengan lainnya, berdasarkan pendapat diatas strategi ini dapat menjadi suatu acuan dimana pemerintah desa ataupun pemerintah daerah manpu mengemas potensi desa tersebut menjadi suatu atraksi wisata yang menarik dan mampu disajikan sesuai dengan potensi desa tersebut. Salah satu potensi yang dapat dikembangkan adalah potensi budaya yang melekat pada desa tersebut secara turun temurun baik dari segi aktifitas sehari - hari, kuliner, kesenian daerah, kerajinan, mata pencaharian dan lain-lain. Hal ini dapat menjadi suatu konsep wisata pedesaan yang mempunyai daya tarik wisata sehingga dapat menarik minat wisatawan lokal, nusantara maupun mancanegara.Kabupaten Minahasa Selatan merupakan salah satu kabupaten yang tebentuk berdasarkan undang-undang nomor 10 tahun 2003 oleh DPR RI, kabupaten Minahasa Selatan merupakan salah satu kabupaten yang mempunyai pusat pemerintahan atau ibukota yaitu Amurang. Minahasa Selatan mempunyai 17 kecamatan dan 117 kelurahan. Dikarenakan potensi Minahasa Selatan yang melimpah sangat mungkin kawasan ini menjadi salah satu destinasi unggulan baru propinsi SulawesiUtara. Dalam penelitian ini akan difokuskan untuk mengidentifikasi potensi desa Tawaang Timur Minahasa 
Selatan sebagai salah satu daya tarik wisata yang kedepannya bisa menjadi suatu desa wisata yang mampu meningkatkan pendapatan masyarakat di desa tersebut.

\section{METODE PENELITIAN}

Penelitian ini bersifat deskriptif kualitatif, dengan melihat potensi daya tarik wisata setempat. Pengumpulan data dengan cara pengamatan langsung terhadap obyek yang diteliti, wawancara terhadap masyarakat lokal Desa Tawaang Timur di Minahasa Selatan,dokumentasi, dan memformulasikan SWOT. Metode tersebut di gabungkan untuk mendapatkan fakta yang terkait dengan kondisi atau wilayah tersebut. Hasil analisis data disajikan secara deskriptif, kemudian dianalisis dengan metode SWOT, artinya hasil analisis dipaparkan sebagaimana adanya dan pada bagian tertentu di interpretasikan sesuai dengan teori dan kerangka pikiran yang berlaku umum. Dengan penyajian secara formal dan informal. dengan demikan Hasil Tersebut akan diperoleh gambaran yang lebih jelas dan mendalam tentang penelitian yang dilakukan.

\section{HASIL DAN PEMBAHASAN}

\section{Sejarah desa Tawaang}

Desa Tawaang, Kecamatan Tenga Kabupaten Minahasa Selatan memang memiliki sejarah yang sangat berliku, sebenarnya Tawaang itu merupakan sebuah tanaman khas Minahasa yang menandakan batas Tanah. Sejarah kisah berdirinya Desa Tawaang dimulai sekitaran tahun 1700an. Pada saat itu Desa Tawaang mula -mula mempunyai penduduk sekitar 15 kepala keluarga atau sekitar 125 orang yang datang dari berbagai daerah di Minahasa dan Mongondow.Penduduk Desa Tawaang pernah tercatat mengungsi ke tempat sebelah timur Desa Tawaang yang tepatnya berada 500 meter diseberang sungai/ kuala Tongop. Semenjak mengungsi akibat banjir maka diceritakan bahwa masyarakat Desa Tawaang menempati tempat pengungsian sangat lama di tempat pengungsian sebelah timur desa Tawaang. di tempat pengungsian orang Tawaang mula -mula juga terdapat pula kelompok masyarakat yang tinggal disuatu tempat kira-kira berjarak $3 \mathrm{Km}$ dari tempat pengungsian masyarakat Tawaang yaitu masyarakat Tumotowa. Kehidupan kedua kelompok ini sangat mempunyai hubungan erat karena sering bersosialisasi antar kelompok dan walaupun hidup terpisah karena berbeda kelompok akan tetapi mereka merasakan mereka adalah satu. Pada suatu ketika masyarakat Desa Tawaang dijangkiti virus penyakit yang sangat misterius dan mengkhawatirkan, sehingga banyak masyarakat Desa yang meninggal. Maka setelah dilakukan perundingan dengan tetua kampung di Pengungsian dengan mempertimbangkan lokasi Pengungsian dan penyakit yang melanda orang Tawaang maka diputuskan bahwa penduduk Tawaang di Pengungsian akan kembali lagi ke lokasi Desa Tawaang yang sebelum terkena banjir. Kejadian kembalinya penduduk ke Desa sekitaran tahun 1918. dan perpindahan Kembalinya orang Tawaang ke lokasi Desa diikuti oleh orang Tumotowa. Hal ini dikarenakan orang Tumotowa memiliki hubungan pertalian erat dengan orang Tawaang sewaktu di pengungsian. maka jadilah Desa tawaang ini memiliki penduduk tambahan orang Tumotowa. Pada tahun 1920 semua masyarakat Desa Tawaang dan masyarakat Desa Tumotowa sudah menyatu dan tinggal di Desa Tawaang sampai sekarang. Masyarakat Tumotowa yang bergabung dengan masyarakat Desa Tawaang berjumlah 40 KK atau sekitar 200 orang. Pada waktu itu Desa Tawaang sedah mempunyai Hukum Tua / Kepala Desa atau Pemerintahan sendiri yang mejadi Hukum Tua yang 
pertama adalah Hendrik Manorek melalui proses pemilihan Hukum Tua. Kemudian di gantikan oleh Derek Kelung pada pemilihan Hukum Tua tahun 1930. Pada masa kepemimpinan Hukum Tua Thiotitus Tampongan goi terjadilah perang Dunia II (PD. II) Jepang menduduki Minahasa pada tanggal 11 Januari 1942 termasuk Desa Tawaang. Kehidupan masyarakat saat itu pada umumnya mulai tertindas, masyarakat dipaksa menanam kapas dibawa pengawasan tentara Jepang. Pada tahun 1943, tentara Jepang membangun lapangan terbang (lokasi pantai Arakan sekarang ini) dalam pembangunan tersebut tentara Jepang mengerahkan sekitar 2000 orang setiap hari dan selesai pada tahun itu juga (1943). Pada tahun 1944 pesawat pembom tentara Sekutu datang menggempur dan menghancurkan lapangan terbang tersebut sehingga hancur lebur. Pada waktu Proklamasi Kemerdekaan RI 17 Agustus 1945, masyarakat masih berada dalam pengungsian. Setelah pasukan Jepang ditarik dari Desa Tawaang, masyarakat Desa Tawaang kembali ke Desa tersebut. Setelah penduduk Desa tawaang begitu banyak maka pada tanggal 24 juni 2007 hukum tua Robby Manerek menyampaikan kepada BPD bahwa Desa Tawaang sudah layak dimekarkan karena jumlah penduduk yang sudah begitu banyak dan mendapatkan respon BPD langsung membentuk panitia pemekaran desa dan mensosialisasikan kepada masyarakat untuk pendataan dan pemetaan. Masyarakat sangat mendukung akan pemekaran maka pada bulan Juli 2007 panitia megajukan permohonan da pengusulan kepada pemerintah kabupaten Minahasa Selatan untuk Desa Tawaang dibagi menjadi 3 desa karena jumlah penduduk sesuai dengan pendataan yaitu $745 \mathrm{KK}$ dan 2485 Jiwa, setelah berkas permohonan dan pengusulan diproses oleh pemerintah kabupaten Minahasa Selatan. Kabupaten Minahasa Selatan menetapkan dengan peraturan daerah bahwa desa Tawaang dimekarkan menjadi 3 Desa yaitu Desa Tawaang, Desa Tawaang Barat dan Desa Tawaang Timur. Maka sejak itulah desa Tawaang Timur berdiri. Desa Tawaang timur pertama kali dipimpin oleh hukum tua atau kepala desa Robby Manorek setelah dikeluarkan Perda yang mengangkatnya. Menurut Nurhayati (dalam Susilo, 2008 :1) desa wisata adalah suatu bentuk integrasi antara atraksi, akomodasi dan fasilitas pendukung yang disajikan dalam suatu struktur kehidupan masyarakat yang menyatu dengan tata cara dan tradisi yang berlaku. Unsur dari desa wisata adalah memiliki potensi wisata, seni, dan budaya khas setempat. Analisa mengidentifikasi potensi dengan ditambah analisa SWOT untuk mengetahui apakah desa Tawaang Timur mampu dijadikan suatu desa wisata yang bermanfaat terhadap pengembangan sektor pariwisata di kabupaten Minahasa Selatan analisa SWOT mencakup : attraction, accessibility, ammenities, Anciliaries) dan community Involvement

\section{Potensi Desa Tawaang Timur}

* Wisata alam

Desa tawaang timur merupakan desa yang berada dekat dengan bibir pantai yag mempunyai potensi yang sangat menarik untuk dikembangkan menjadi desa wisata.

\section{Pantai Moinit}

Pantai Moinit yang terletak di desa Tawaang Timur memiliki keindahan dan eksotis air panas laut ternyata menyimpan sejarah perkembangan suku Minahasa, di wilayah ini menurut salah satu 
pengelola pantai merupakan salah satu markas Opa Oraas Soputan yang merupakan salah satu pejuang yang sangat pemberani yang dipunyai suku Minahasa, Moinit sendiri mempunyai asal kata 'moongiung' yang berasal dari bahasa Mongondow dalam bahasa sehari - hari "mari kita ke atas". Pada tahun 1873, Moinit diserang oleh suku Mongondow namun Opa Oraas Soputan berhasil mengusir musuh dan mereka berhasil lari kedaerah desa Poigar sampai saat ini. Namun setelah usai serangan itu, mereka diserang lagi oleh suku dari Filipina selatan yakni Mangindano, serangan yang bertubi - tubi berhasil dipertahankan dan dimenangkan oleh pejuang dari Minahasa. Pantai Moinit berada sekitar 30 menit dari Amurang dan berada di belakang sekolah Balai Diklat Pelayaran Minahasa Selatan, pantai ini mempunyai pemandangan yang menghadap langsung ke laut Sulawesi, selain itu pantai ini mempunyai air panas laut yang berasal dari gunung Soputan.

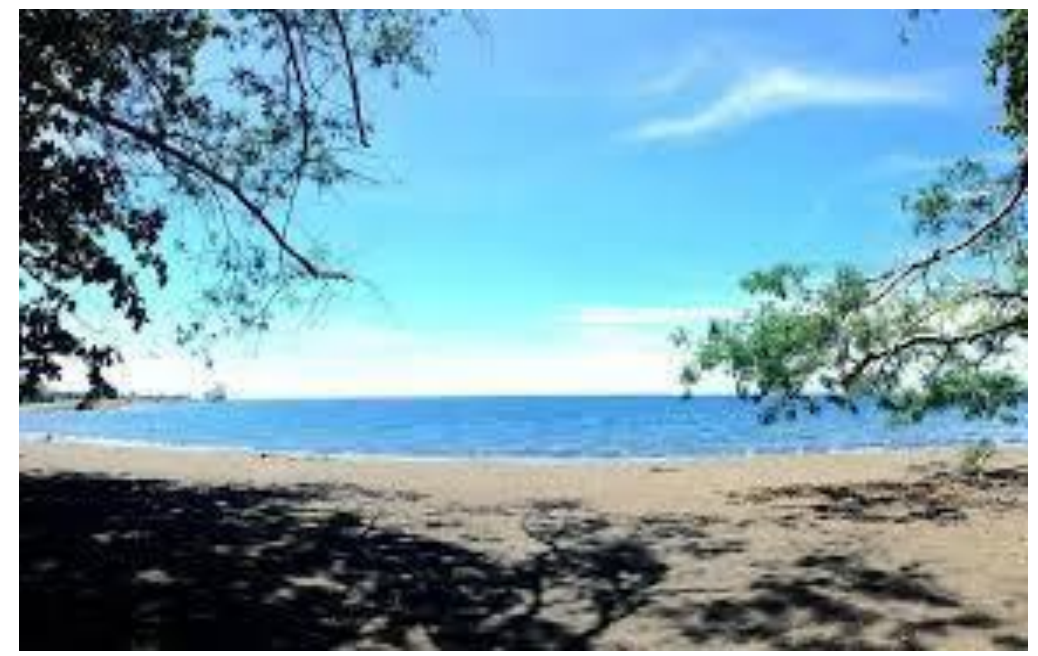

Pantai moinit

Pantai songkur

Pantai songkur merupakan pantai yang terdapat di dekat PLTU II Sulawesi Utara (Amurang), pantai ini bertepatan dekat dengan salah satu kapal pembangkit listrik, dengan lokasi yang lumayan tersembunyi pantai ini mempunyai keindahan yang alami dan menarik.

\section{Bedungan BTO}

Bendungan BTO merupakan bendungan yang terletak di desa Tawaang Timur tetapi bendungan ini kurang terekpos dikarenakan letak bendungan yang infrastruktur kurang memadai sehingga akses untuk menuju kesana harus berjalan kaki agak menanjak dengan medan yang cukup menantang

Seni dan budaya 
Desa Tawaang Timur merupakan salah satu desa yang kental dengan suku minahasa, seni dan budaya minahasa seperti music bamboo/ clarinet, kolintang bisa dijumpai di daerah tersebut selain itu mulai bermunculannya kreatifitas masyarakat dalam menciptakan seni tari yang terinspirasi dengan kondisi masyarakat

sekitar

\section{Tari kebesaran}

Tari ini merupakan salah satu tarian perang yang masih dipergunakan oleh masyarakat setempat untuk penyambutan tamu kehormatan, tarian ini dibudayakan turun temurun dari sesepuh dan sampai ke anak muda di desa tawaang timur

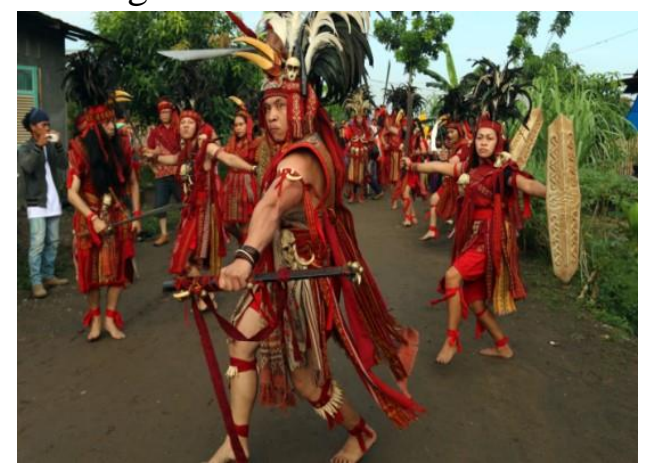

Tari Kebesaran

\section{Tari Maengket}

Tari maengket merupakan tarian tradisional Minahasa yang berkembang sampai zaman sekarang, tarian ini ada sejak rakyat di Minahasa mengenal pertanian,dan memiliki gerakan - gerakan yang sederhana, dengan berjalannya waktu tarian ini berkembang bentuk menjadi istimewa tanpa meninggalkan keasliannya terdapat berbagai macam gerakan - gerakan baru dan babak sehingga menjadi lebih menarik dan indah.

\section{Tari Lenso}

Adalah tarian yang menggambarkan kehidupan muda - mudi dalam pergaulan sehari - hari warga setempat dalam mencari pesangan, penari tersebut akan membawa lenso yang berarti sapu tangan untuk mentukan pasangan hidupnya kelak.

Tari dodol dan budaya pengucapan

Budaya pengucapan merupakan salah satu tradisi masyarakat minahasa pada umumnya,hari raya ini sudah melekat pada masyarakat Minahasa sejak zaman dahulu. Tidak ada yang tahu pasti sejak kapan tradisi ini dimulai namun masyarakat Minahasa sudah melakukan tradisi ini turun temurun dari leluhur mereka sehingga hal ini sudah menjadi bagian dari budaya mereka. 
Pengucapan syukur dulunya merupakan hari sesudah panen besar yang dilakukan oleh etnis atau suku minahasa, masa sesudah panen dirayakan oleh masyarakat adat dengan membagikan hasil panen kepada keluarga atau kerabat terdekat maupun pesta rakyat, dengan menikmati hasil panen dan diringi tarian dodol, merupakan wujud ungkapan rasa syukur masyarakat terhadap pemberian rahmat tuhan kepada mereka. Budaya minuman cap Tikus

Di desa tawaang timur terdapat pohon aren yang menjadi cikal bakal untuk minuman tradisional masyarakat disana, proses pengolahan yang tradisional menjadi salah satu keunggulan apabila dikelola dengan professional dan menjadi salah satu wisata edukasi untuk wisatawan yang tertarik untuk mengetahui cara pembuatan minuman alcohol bernama cap tikus.

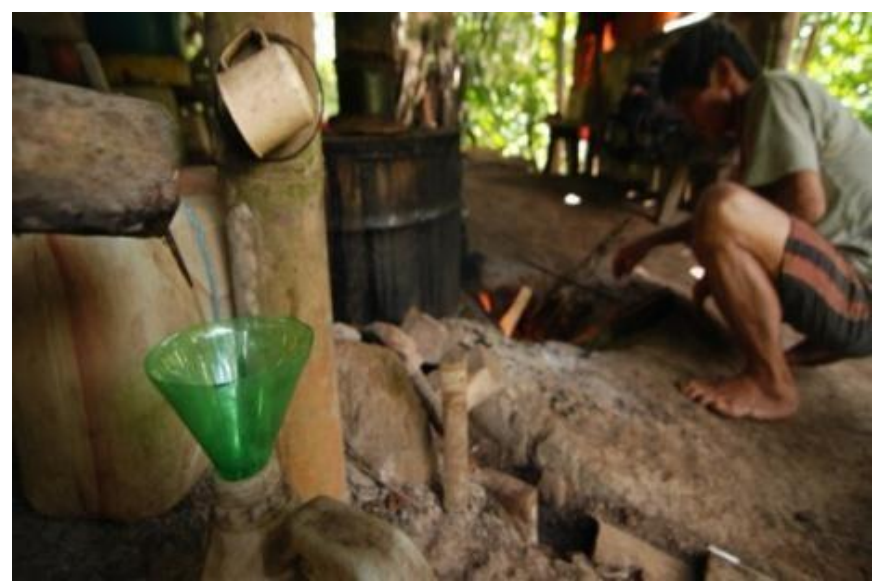

pengolahan cap tikus secara tradisional

Wisata ekologi

Desa Tawaang Timur memiliki ekologi, yaitu pertanian, perkebunan dan hutan Bakau atau mangrove yang terletak disana. Selain factor pertanian dan perkebunan yang menunjang, wisata mangrove belum digarap optimal padahal potensi ini bisa dijadikan peningkatan sektor pariwisata di desa tersebut.

\section{Analisa SWOT}

Analisa SWOT digunakan untuk mengetahui sejauh mana keuggulan atau potensi desa Tawaang timur untuk menjadi desa wisata yang mampu menjadi andalan daerah dalam mengembangkan sektor pariwisatanya, analisa SWOT tersebut untuk mengetahui segi - segi seperti 4A dan CI (attraction, accessibility, ammenities, Anciliaries) dan community Involvement. 
Karena penelitian ini menggunakan SWOT Analisis maka dalam presentasi hasil dan pembahasan perlu dibuatkan matrix SWOT (yang menjadi bobot penelitian ini) dan harus memperhatikan aspek-aspek analisis SWOT itu sendiri yaitu External Factor Evaluation (EFE) dan Internal Factor Evaluation(IFE). Matriks EFE merupakan daftar serangkaian faktor strategis eksternal, yang terdiri atas peluang dan ancaman. Matriks IFE digunakan untuk mengetahui faktor-faktor berkaitan dengan kekuataan dan kelemahan yang dianggap penting. Setelah menganalisis dengan matriks IFE dan EFE maka dilakukan berbagai kombinasi dengan menggunakan matriks SWOT. Matriks ini merupakan matching tool untuk mengembangkan 4 tipe strategi:

(1) Strategi SO (Strengths-Opportunities), memanfaatkan atau mengoptimalkan kekuatan yang dimiliki/Strengths (S) untuk memanfaatkan berbagai peluang/Opportunities (O).

(2) Strategi WO (WeaknessesOpportunities),seoptimal mungkin meminimalisir kelemahan/Weaknesses $(\mathrm{W})$ yang ada untuk memanfaatkan peluang/Opportunities $(\mathrm{O})$.

(3) Strategi ST (Strengths-Threats), memanfaatkan atau mengoptimalkan kekuatan yang dimiliki/Strengths (S) untuk mengurangi berbagai ancaman/Threats $(\mathrm{T})$.

(4) Strategi WT (Weaknesses-Threats), mengurangi kelemahan/Weaknesses (W)dalam rangka meminimalisir/menghindari ancaman/Threats $(\mathrm{T})$.

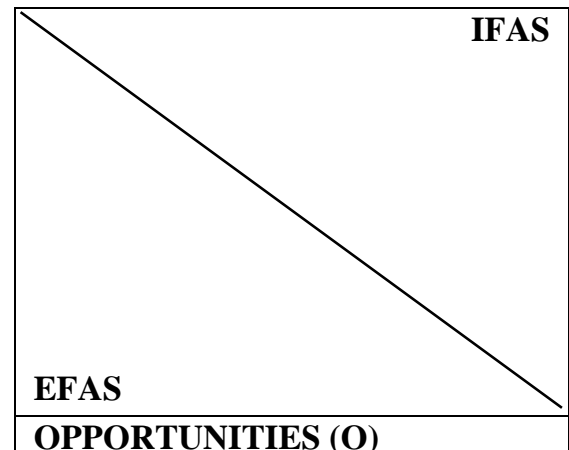

Daftar Semua Peluang yang dapat diidentifikasi

- Meningkatkan potensi daya tarik wisata alam

- Menjaga dan mempertahakan seni budaya local

- Membuat komodifikasi terhadap seni dan budaya

- Membuat kerajinan baru

THREATS (T)

Daftar semua ancaman yang dapat diidentifikasi

- Persaingan dari desa lain terhadap daya tarik wisata baru
STRENGTHS (S)

Daftar Kekuatan yang dimiliki

- Daya tarik wisata alam yang alami dan mempunyai potensi yang besar

- Kesenian yang selama ini ada

- Budaya yang selama ini masih kental dan belum hilang tergerus oleh perkembangan zaman

STRATEGI SO

Strategi yang menggunakan kekuatan untuk memanfaatkan peluang

- Meningkatkan potensi daya tarik wisata yang sudah ada atau baru

- Meningkatkan, menjaga da mempertahankan budaya local dan kesenian serta membuat komodikasi dalam bidang seni dan budaya local

- Memberikan pelatihan serta pendaaan untuk membuat seni kerajinan baru

\section{STRATEGI ST}

Strategi yang menggunakan kekuatan untuk mengatasi ancaman

- Peningkatan iklan dan promosi terhadap desa wisata da potensi -
WEAKESS (W)

Daftar Semua Kelemahan yang dimiliki

- Infrastruktur yang kurang memadai

- SDM yang sangat kurang dalam mengenal pariwisata

- Keterlibatan pemerintah dalam mengembangkan wisata

\section{STRATEGI WO}

Strategi yang meminimalkan kelemahan untuk memanfaatkan peluang

- Pembuatan infrastruktur yang memadai untuk meningkatkan akses kedaerah wisata

- Memberikan pelatihan SDM terhadap pegelolaan pariwisata di desa tersebut

- Menjalin kerjasama untuk meningkatkan kesinergitasan antara desa dengan pemerintah daerah

\section{STRATEGI WT}

Strategi yang meminimalkan kelemahan dan menghindari ancaman

- Perbaikan infrastruktur wisata seperti jalan, toilet,tempat sampah, 


\section{Opportunity}

Kesempatan Desa Tawaang Timur sangat banyak, potensi alam, seni dan budaya seharusnya mampu di ekplor lebih dalam dan dipersiapkan lebih matang untuk menjadi desa wisata karena desa ini mempunyai potensi - potensi yang sangat jarang terdapat di desa lain,seni tradisional perlu dibentuk dan ditradisikan ke anak - anak remaja dan muda, dibuatkan sanggar - sanggar tari untuk membentuk karakter seni dan budaya warga dan bisa ditampilkan di depan wisatawan yang mengunjungi tempat - tempat yang berpotensi, pelatihan kerajinan tangan untuk membuat benda - benda cendera mata yang bisa dijadikan penggerak ekonomi wisata.

Threat

Desa Tawaang Timur memiliki ancaman apabila mereka terlambat atau tidak memikirkan sektor pariwisata menjadi andalan desa tersebut, ancaman bisa datang dari desa lain yang mempunyai keinginan dan potensi untuk menjadi desa wisata. Selain ancaman persaingan yaitu ancaman dari budaya setempat yang terdegradasi karena perkembangan teknologi sehingga akar dari budaya lama - kelamaan akan hilang

\section{SIMPULAN}

Dari kesimpulan analisis SWOT diatas Desa Tawaang Timur mempunyai daya tarik potensi alam, seni dan budaya untuk dikembangkan menjadi desa wisata, tetapi pemenuhan unsur seperti (attraction, accessibility, ammenities, Anciliaries) dan community Involvement harus dipertimbangkan secara benar dan matang, penggunaan analisa SWOT yang peneliti lakukan harus menjadi bahan panduan untuk menentukan langkah - langkah pengembangan desa wisata agar bisa menjadi salah satu desa wisata yang menjadi kebanggaan pemerintah daerah serta masyarakat yang tinggal daerah tersebut.

\section{Rekomendasi}

Desa Tawaang Timur merupakan salah satu desa yang mempunyai potensi alam, seni dan budaya yang sangat jarang ditemui di tempat lain, seharusnya potensi tersebut mampu dikembangkan menjadi desa wisata yang mampu menggerakkan perekonomian warga setempat. Peran serta pemerintah, LSM dan masyarakat harus ditingkatkan mengingat masih banyaknya faktor infrastruktur yang sangat tidak memadai begitu juga faktor - faktor lain. 


\section{DAFTAR RUJUKAN}

Daldjoeni, N. 1998, Geografi Kota dan Desa, Bandung Alumni Bandung. Hardaniwati dkk. 2003, Kamus Pelajar Sekolah Lanjutan Tingkat Pertama, Jakarta : Pusat Bahasa

Komaruddin dan Yooke Tjuparmah 2000, Kamus istilah karya tulis ilmiah, Bumi Aksara. Jakarta Latupapua, Y.T. 2011. Persepsi Masyarakat Terhadap Potensi Objek Daya Tarik Wisata Pantai di Kecamatan Kei KecilKabupaten Maluku Tenggara. Jurnal Kehutanan Fakultas Pertanian. Vol. VI. No. 2. Juni 2011. (http : // jurnalee.files.wordpress.com/2012/12/ persepsi-masyarakat-terhadap-potensiobjek-dayatarik-wisata-pantai.pdf, diakses 6 Maret 2013).

Majdi, U.Y. Efendi. 2007,QuranicQuotient.Jakarta : Qultum Media

Pendit, Nyoman, S. 1994, Ilmu Pariwisata (Sebuah Pengantar Perdana). Jakarta : Pradnya Paramita

Pendit, Nyoman, S. 1999, Ilmu Pariwisata. Jakarta : Akademi Pariwisata Trisakti

Soedarsono, R.M. 1999, Seni Pertunjukan dan pariwisata. Yogyakarta : ISI Yogyakarta)

Sugianto Alip. 2016, Kajian Potensi Desa Wisata Sebagai Peningkatan Ekonomi Masyarakat Desa Karang Patihan Kecamatan Balong Ponorogo.Jurnal Ekuilibrium. Volume 11, Nomor 1.Maret 2016.

Sujali,1989.Geografi Pariwisatadan Kepariwisataan. Diklat Yogyakarta : Universitas Gajah Mada Yogyakarta

Susilo, Sri. 2008. Penilaian Ekonomi Desa Wisata kasus : Desa Kepuharjo, Sleman, Yogyakarta : jurnal OPTIMAL Volume 6 Nomor 1

Wardiyatmo, 2013. Sektor Pariwisata Turut Dongkrak Perekonomian, Harian Suara Pembahuruan edisi Senin 30April2012 http://www.suarapembaruan.com/ekon omidanbisnis/sektor-pariwisata-turut-d ongkrakperekonomian/19621di akses pada Jumat, 29 Maret 2013 pukul 17.30 wita

Wulan T.dan Khadiyanto P.2013,Identifikasi Potensi dan Masalah DesaWonosoco DalamUpaya Pengembangan Sebagai Desa Wisata di Kabupaten Kudus. Jurnal RUANG. Volume 1 Nomor 1.2013

Yoeti, O. A. 2008. Perencanaan dan Pengembangan Pariwisata. Jakarta: Pradyana 